\title{
MOTILITAS DAN ABNORMALITAS SPERMATOZOA BANGSA PEJANTAN SETELAH PENYIMPANAN
}

\author{
Mohamad Ervandi \\ Program Studi Peternakan Universitas Muhammadiyah Gorontalo \\ email: ervandi_husain@yahoo.co.id
}

\begin{abstract}
This research aims to study influence of the breed chicken toward motility, abnormality, and durability of live spermatozoa after storage at a temperature of $4^{\circ} \mathrm{C}$. Cement of chicken that using in this research come from 3 chickens male with the different there are chicken laughing, chicken arab, and chicken burma. The design of this research is laboratories experimentaly by using random design complete steel and torrie (1991), consisting of 3 treatment and 6 remedial ( the number of cement). The kinds of male chicken that used: $P 1$ = male of chicken laughing, P2 = male of chicken arab, P3 = male chicken burma. The results of the diversity analysis showed that the chicken laughing and chicken arab have an influence significantly $(P<0,01)$ to motility of progressive spermatozoa( $P 1=79,88 \%, P 2=$ $76,53 \%, P 3=84,25 \%)$, abnormality of spermatozoa $(P 1=5,00 \%, P 2=5,54 \%, P 3=4,46 \%)$, and durability life of spermatozoa ( $P 1=72,67 \%, P 2=70,83 \%, P 3=74,83 \%)$. From the results of the research obtained that the burma chicken better in maintaining motility, abnormality, and durabilty of live spermatozoa after storage at the temperature of $4^{\circ} \mathrm{C}$
\end{abstract}

Keyword : Male Breed, Storage Spermatozoa

\begin{abstract}
Abstrak
Penelitian ini bertujuan mempelajari pengaruh bangsa ayam terhadap motilitas dan abnormalitas setelah penyimpanan pada suhu $4^{\circ} \mathrm{C}$. Semen ayam yang digunakan dalam penetian ini berasal dari 3 ekor ayam jantan dengan bangsa pejantan yang berbeda yaitu ayam ketawa, ayam arab, dan ayam birma. Rancangan penelitian ini adalah ekperimental laboratoris dengan menggunakan Rancangan Acak Lengkap Steel dan Torrie (1991), yang terdiri dari 3 perlakuan dan 6 ulangan (jumlah penampungan semen).Jenis ayam pejantan yang digunakan : $\mathrm{P} 1=$ pejantan ayam ketawa, $\mathrm{P} 2=$ pejantan ayam arab, $\mathrm{P} 3=$ pejantan ayam birma. Hasil analisis keragaman memperlihatkan bahwa bangsa ayam ketawa, ayam arab, dan ayam birma memberikan pengaruh yang sangat nyata $(P<0,01)$ terhadap Motilitas progresif spermatozoa $(\mathrm{P} 1=79,88 \%, P 2=76,53 \%, \quad \mathrm{P} 3=84,25 \%)$ dan Abnormalitas Spermatozoa ( $P 1=5,00 \%, P 2=5,54 \%, P 3=4,46 \%$ ). Dari hasil penelitain diperloleh bahwa semen ayam birma lebih baik dalam mempertahankan motilitas dan abnormalitas spermatozoa setelah penyimpanan pada suhu $4^{\circ} \mathrm{C}$
\end{abstract}

Kata Kunci :Bangsa Pejantan, Penyimpanan spermatozoa

\section{PENDAHULUAN}

Subsektor Peternakan merupakan salah satu bagian terpenting dalam penyedia bahan pangan asal ternak.
Indonesia dengan jumlah populasi penduduk yang cukup besar, seharusnya mempunyai populasi ternak yang tinggi sebagai penyedia pangan hewani. Namun, secara realistis jumlah populasi 
ternak di Indonesia belum sebanding dengan kebutuhan masyarakat akan protein hewani yang semakin meningkat, sehingga perlu upaya alternatif dalam memenuhi kebutuhan protein hewani dengan mengembangkan potensi genetik ternak diantaranya adalah ternak ayam.

Secara umum ayam dapat dibedakan menjadi dua kategori yaitu ayam yang telah banyak mengalami perbaikan mutu genetik dan ayam yang belum banyak mengalami perbaikan mutu genetik, maka terbuka peluang untuk melakukan pemuliabiakan jenis ternak yang produktifitasnya lebih baik. Hasil penelitian Ridwan (2002) menjelaskan bahwa salah satu proses pemuliabiakan yang dapat dilakukan pada tahap awal adalah seleksi dan persilangan antara bangsa ayam - ayam terpilih, yaitu melalui Inseminasi Buatan. IB pada ayam merupakan salah satu teknik perkawinan secara buatan dengan memasukkan semen ke dalam saluran reproduksi ayam betina yang sedang masa produksi (Ridwan, 2002).

Faktor yang menentukan keberhasilan teknologi IB diantaranya adalah penggunaan semen yang berasal dari bangsa ayam pejantan dan mutu genetik yang baik, seperti bobot tubuh ternak. Bobot tubuh berperan sangat penting dalam menentukan kuantitas dan kualitas semen. Ternak yang ukuran tubuhnya lebih besar akan memiliki jaringan testikular lebih besar yang pada akhirnya mampu menghasilkan semen lebih baik. Selain bangsa pejantan, penyimpanan semen juga menentukan keberhasilan IB. Sejauh ini IB pada unggas hanya menggunakan semen segar atau tanpa bahan pengencer, hal ini mempunyai kendala, karena semen sesudah ditampung pada suhu kamar harus dipakai tidak lebih dari dua jam (Toilihere, 1993). Idealnya, semen harus dapat disimpan dalam jangka waktu yang lama sesudah penampungan namun tetap dapat mempertahankan daya fertilisasinya. Olehnya, semen perlu dicampur dengan larutan pengencer yang menjamin kebutuhan fisik dan kimianya sehingga masih layak digunakan untuk IB setelah beberapa waktu.

Umumnya semen cair yang dipakai untuk IB disimpan pada temperatur $4^{\circ} \mathrm{C}$ $5^{\circ} \mathrm{C}$, ini bertujuan untuk mengurangi laju metabolisme, menghambat

perkembangan mikroorganisme, dan memperpanjang umur spermatozoa sehingga akan dicapai efisiensi penggunaan pejantan (Purwanti, 2006).

\section{METODE PENELITIAN}

Semen ayam yang digunakan dalam penetian ini berasal dari 3 ekor ayam jantan dengan bangsa pejantan yang berbeda yaitu ayam ketawa, ayam arab, dan ayam birma. Pengencer semen yang digunakan adalah jenis pengencer Ringer Laktat ditambah.

Peralatan yang digunakan tabung reaksi berskala, mikroskop, satu set haemocytometer, lemari pendingin, gelas objek, kertas $\mathrm{pH}$, aluminium foil, pipet, gunting, rak tabung dan kertas tissue.

Kandang yang digunakan pada ayam jantan, kandang dibuat dari bambu bentuk little yang dibuat secara individualdengan ukuran kandang : panjang $60 \mathrm{~cm}$, lebar 60 $\mathrm{cm}$ dan tinggi $75 \mathrm{~cm}$.

Pakan yang digunakan dalam penelitian ini terdiri dari campuran pakan komersial Superfeed (PT Cheil Jedang Indonesia), jagung, dan dedak dengan perbandingan $15 \%: 50 \%$ : $35 \%$. Pemberian pakan 2 kali sehari pada pagi dan sore hari.

Rancangan penelitian ini adalah ekperimental laboratoris dengan menggunakan Rancangan Acak Lengkap (Steel dan Torrie, 1991) yang terdiri dari 3 
perlakuan dan 6 ulangan (jumlah penampungan semen). Apabila hasil analisis keragaman menunjukan pengaruh yang nyata dari perlakuan maka dilanjutkan dengan menggunakan uji lanjut Beda Nyata Terkecil (BNT).

Perlakuan yang di cobakan adalah sebagai berikut $P_{1}$ : Semen ayam ketawa, $P_{2}$ : Semen ayam arab, $P_{3}$ : Semen ayam Birma.

Penampungan semen dilakuan pada sore hari sekitar pukul 16:00 WITA. Penampungan semen dilakukan berdasarkan metode Burrows dan Quinn (1985) yang digunakan dengan cara pengurutan atau (masase). Adapun caracara yang harus dilakukan adalah : kedua kaki ayam dipegang dengan tangan kiri dengan posisi tubuh horizontal menghadap badan. Selanjutnya punggung ayam diurut dengan telapak tangan kanan dari belakang pangkal leher menuju bagian pangkal ekor. Satu orang lainya yang membantu proses penampungan semen dan tissue untuk membersihkan kotoran ayam. Melakukan pengurutan beberapakali sampai terjadi rangsangan pada ayam yang ditandai adanya perenggangan tubuh ayam dan keluarnya papillae dari proktodeum kloaka. Ketika reaksi mencapai maksimal, ibu jari dan telunjuk tangan kanan pengurut dikedua sisi kloaka, sehingga dari papillae keluar semen berwarna putih susu. Semen yang keluar segera ditampung oleh orang kedua dengan cara menyandarkan mulut tabung reaksi berskala pada kloaka. Penampungan semen dilakukan dengan interval tiga hari sekali.

\section{Varibel yang diamati}

\section{Motilitas Spermatozoa}

Perhitungan motilitas spermatozoa adalah persentase dari hasil pembagi jumlah spermatozoa motil terhitung dengan spermatozoa total. Maka persentase motalitas spermatozoa diperoleh berdasarkan rumus modifikasi Ridwan (2002):

Motilitas

$=\frac{\text { Tlt spermatozoa }- \text { Tlt Spermatozoa tidak motil }}{\text { Tlt Spermtozoa }} \times 100 \%$

\section{Abnormalitas Sekunder Spermatozoa}

Abnormalitas spermatozoa diperoleh dengan cara menghitung spermatozoa yang abnormal dengan membuat preparat ulas dan diamati di bawah mikroskop dengan pembesaran $10 \times 40$. Adapun cara perhitungan abnormalitas spermatozoa adalah jumlah dari spermatozoa yang abnormal dibagi dengan 200 spermatozoa yang terlihat dikali seratus persen. Menurut Ridwan (2002) Persentase abnormalitas spermatozoa di peroleh dengan rumus :

$$
\begin{aligned}
& \text { Abnormalitas } \\
& =\frac{\text { Spermatozoa Abnormal }}{\text { Total Spermatozoa diamati }} \times 100 \%
\end{aligned}
$$

\section{HASIL DAN PEMBAHASAN}

\section{Kualitas Semen Segar}

Data hasil evaluasi semen segar yang digunakan dapat dilihat pada Tabel 1. Hasil pengamatan secara makroskopis pada semen tiga jenis bangsa ayam menunjukkan bahwa volume ejakulat ratarata 0,2 - 0,4. Rata - rata volume semen tersebut sesuai dengan yang dikemukakan oleh Toelihere (1993) yaitu 0,2 - 0,4 $\mathrm{ml}$ dimana kisaran ini berbeda beda menurut bangsa unggas. 
Tabel 1. Rata - rata kualitas semen segar tiga jenis pejantan.

\begin{tabular}{lccc}
\hline $\begin{array}{c}\text { KarasteristikSemen } \\
\text { Segar }\end{array}$ & $\begin{array}{c}\text { Ayam } \\
\text { Ketawa }\end{array}$ & $\begin{array}{c}\text { Ayam } \\
\text { Arab }\end{array}$ & $\begin{array}{c}\text { Ayam } \\
\text { Birma }\end{array}$ \\
\hline \multicolumn{1}{c}{ Makroskopis : } & & & \\
Volume (ml) & 0,2 & 0,3 & 0,4 \\
$\mathrm{pH}$ & 7,8 & 7,7 & 7,6 \\
Warna & Krem & Krem & Krem \\
Konsistensi & Kental & Kental & Kental \\
Gerakan Massa & +++ & +++ & +++ \\
$\quad$ Mikroskopis : & & & \\
Konsentrasi(10 $)$ & 2,8 & 3,04 & 3,47 \\
Motilitas (\%) & 90 & 91,8 & 92,3 \\
Abnormalitas(\%) & 2,5 & 3,0 & 2,5 \\
\hline
\end{tabular}

Keterangan : +++ : Sangat baik, (terlihat banyakgelombang besar yang bergerak cepat).

Derajat keasaman $\mathrm{pH}$ adalah $7,6-7,8$ dimana menurut Hidajat (2000), pH semen ayam 7,5-7,8 masih dalam kisaran normal. Warna dan kosistensi semen adalah kental dan krem, tidak tembus dengan cahaya hal ini sesuai yang dikemukakan Suprijatna et al (2005) bahwa semen yang berkualitas baik berwarna krem dan tidak tembus dengan cahaya yang menunjukkan konsentrasi tinggi. Konsentrasi spermatozoa ayam berkisar $2,8 \times 10^{9}-3,47 \times 10^{9}$. Hal ini sesuai yang dikemukakan Suprijatna (2005) yakni 1,7 x $10^{9}-3,5 \times 10^{9}$. Gerakkan massa spermatozoa ini tergolong kategori sangat baik (+++). Hal ini menunjukkan bahwa spermatozoa yang terkandung dalam semen, diperoleh selama penelitian sangat tinggikartasudjana (2001). Motilitas yang diperoleh selama penelitian sangat baik hal ini sejalan dengan Irastuti (2007) yang menyatakan kategori peresentase motilitas spermatozoa baik yaitu 80$100 \%$. Abnormalitas 2,5-3\%. Menurut Partodiharjo (1992) semen yang baik tidak boleh mengandung spermatozoa abnormal lebih dari $15 \%$. Berdasarkan hasil pegamatan kualitas semen segar dari tiga jenis bangsa ayam menunjukkan bahwa spermatozoa tersebut dinyatakan sangat baik.

\section{Pengaruh Perlakuan Terhadap Motilitas Spermatozoa}

Rataan persentase motilitas progresif spermatozoa pada berbagai jenis bangsa ayam setelah penyimpanan pada suhu $4{ }^{\circ} \mathrm{C}$ disajikan pada Tabel 1. Hasil analisis ragam menunjukkan bahwa perlakuan memberikan pengaruh yang sangat nyata $(P>0,01)$ terhadap motilitas progresi spermatozoa. Berdasarkan $\mathrm{Uji}$ Lanjut Beda Nyata Terkecil (BNT) menujukkan perlakuan semen ayam birma (P3) berbeda sangat nyata $(P>0,01)$ dengan perlakuan semen ayam ketawa (P1) dan perlakuan semen ayam arab (P2) sedangkan (P1) berbeda sangat nyata dengan $(\mathrm{P} 2)$.

Tingginya motilitas spermatozoa yang diperoleh dari perlakuan P3 diguga karna adanya perbedaan kualitas semen segar akibat adanya pengaruh genetic pada masing -masing pejantan diantara ketiga bangsa tersebut, dimana diketahui motilitas semen dari ayam Birma lebih baik dari semen ayam Ketawa dan ayam Arab. Menurut Sitomorang (2002) penurunan motilitas spermatozoa setelah pendinginan disebabkan karena turunya kandungan phospolid dan kolesterol pada masing - masing bangsa, dan pejantan, kedua senyawa tersebut merupakan komponen membrane. Phospolipid berfungsi untuk melindungi sel spermatozoa dari cold shock, sedangkan kolesterol berperan penting dalam menjaga Integritas sel spermatozoa dari variasi sitem membrane yang bertambah selama proses pendinginan. Motilitas mempunyai korelasi positif dengan fertilitas, semakin tinggi jumlah spermatozoa motil maka semakin tinggi fertilitasnya (Salmin, 2000) lebih lanjut dinyatakan bahwa minimal $40 \%$ 


\begin{tabular}{|c|c|c|c|}
\hline Tabel 2 & $\begin{array}{l}\text { aan Moti } \\
\text { Spermatozoa } \\
\text { bangsa } \\
\text { Disimpan par }\end{array}$ & $\begin{array}{l}\text { itas } \mathrm{Pr} \\
\text { pada be } \\
\text { yam } \\
\text { la Suhu } 4\end{array}$ & $\begin{array}{l}\text { ogresif } \\
\text { erbagai } \\
\text { Setelah } \\
\text { C. }\end{array}$ \\
\hline \multirow{3}{*}{ Ulangan } & \multicolumn{3}{|c|}{ Perlakuan } \\
\hline & P1 & $\mathrm{P} 2$ & P3 \\
\hline & \multicolumn{3}{|c|}{. } \\
\hline 1 & 79,20 & 79,20 & 80,20 \\
\hline 2 & 77,60 & 77,70 & 82,80 \\
\hline 3 & 78,50 & 76,20 & 83,40 \\
\hline 4 & 76,00 & 78,50 & 81,20 \\
\hline 5 & 75,70 & 78,90 & 83,30 \\
\hline 6 & 77,30 & 79,70 & 84,70 \\
\hline Total & 475,30 & 467,20 & 495,50 \\
\hline Rata- Rata & $79,88^{a}$ & $76,53^{b}$ & $84,2^{c}$ \\
\hline \multicolumn{2}{|c|}{$\begin{aligned} & \text { Keterangan: } \text { Rataan } \\
& \text { superskrip } \\
& \text { berbeda } \\
& \text { perbedaan } \\
& \text { nyata. }\end{aligned}$} & $\begin{array}{l}\text { yang } \\
\text { huruf } \\
\text { menur } \\
\text { yang }\end{array}$ & $\begin{array}{r}\text { diikuti } \\
\text { yang } \\
\text { jukkan } \\
\text { sangat }\end{array}$ \\
\hline
\end{tabular}

spermatozoa motil diperlukan dalam dosis IB jika kurang dari pesentase tersebut maka potensi untuk membuahi sangat rendah.

\section{Pengaruh Perlakuan Terhadap Abnormalitas Spermatozoa}

Hasil analisis menunjukkan bahwa perlakuan memberikan pengaruh yang sangat nyata $(P<0,01) \quad$ terhadap abnormalitas spermatozoa.Berdasarkan Uji Lanjut Beda Nyata Terkecil(BNT) menunjukkan perlakuan semen ayam $\operatorname{arab}\left(P_{2}\right)$ berbeda sangat nyata $(P<0,01)$ dengan perlakuan semen ayam ketawa $\left(P_{1}\right)$ dan perlakuan semen ayam birma $\left(P_{3}\right)$ sedangkan $P_{1}$ berbeda sangat nyata dengan $\mathrm{P}_{3}$.

Rataan persentase abnormalitas spermatozoa tertinggi pada hasil penelitian ini adalah 5,54\% $\mathrm{P}_{2}$ (ayam arab), kemudian $\mathrm{P}_{1}$ (ayam ketawa) sebesar $5,00 \%$ dan yang terendah adalah $\mathrm{P}_{3}$ (ayam birma) sebesar $4,46 \%$. Spermatozoa pada berbagai bangsa Ayam Setelah Disimpan pada Suhu $4^{\circ} \mathrm{C}$.

\begin{tabular}{|c|c|c|c|}
\hline \multirow{3}{*}{ Ulangan } & \multicolumn{3}{|c|}{ Perlakuan } \\
\hline & $\mathrm{P} 1$ & $\mathrm{P} 2$ & $\mathrm{P} 3$ \\
\hline & \multicolumn{3}{|c|}{$\ldots \ldots \ldots \ldots \ldots \ldots \% \ldots \ldots \ldots \ldots \ldots \ldots \ldots \ldots \ldots$} \\
\hline 1 & 4,60 & 5,80 & 4,20 \\
\hline 2 & 4,50 & 5,60 & 4,40 \\
\hline 3 & 5,80 & 5,90 & 4,50 \\
\hline 4 & 4,30 & 5,50 & 4,60 \\
\hline 5 & 5,20 & 5,60 & 4,20 \\
\hline 6 & 5,90 & 5,50 & 4,60 \\
\hline Total & 31,00 & 34,20 & 27,50 \\
\hline \multicolumn{4}{|l|}{ Rata- } \\
\hline Rata & $5,00^{a}$ & $5,54^{b}$ & $4,46^{c}$ \\
\hline Keterangan & $\begin{array}{l}\text { : Rataan } \\
\text { superskrip } \\
\text { berbeda } \\
\text { perbedaan } \\
\text { nyata. }\end{array}$ & $\begin{array}{l}\text { yang } \\
\text { huruf } \\
\text { menunju } \\
\text { yang s }\end{array}$ & $\begin{array}{l}\text { kuti } \\
\text { ang } \\
\text { kan } \\
\text { gat }\end{array}$ \\
\hline
\end{tabular}

Perbedaan abnormalitas spermatozoa diduga karena adanya pengaruh perbedaan bangsa ayam. Purwanti(2006) menyebutkan bahwa genetic jugamempengaruhi ketahanan sel spermatozoa saat pendinginan dan saat thawing. Evans dan Maxwell (1987) menyatakan bahwa abnormalitas spermatozoa tidak lebih dari $15 \%$, masih bisa dipergunakan untuk inseminasi buatan.

Penentuan jumlah dan macam Abnormalitas spermatozoa di dalam suatu ejakulat harus dipakai secara bersamaan dengan pemeriksaan-pemeriksaan lain yang dilakukan segera setelah penampungan semen seperti penentuan motilitas, konsentrasi dan jumlah spermatozoa hidup dan mati (Toelihere, 1993). Sel spermatozoa yang normal terdiri dari kepala, leher bagian tengah (badan) dan ekor yang tidak menyimpang. Beberapa bentuk penyimpangan dari morfologi dianggap abnormalitas, antara 
lain, sel spermatozoa dengan kepala raksasa atau kerdil, kepala rangkap,ekor melingkar, spermatozoa tanpa kepala atau ekor Shophiani (2006).

\section{KESIMPULAN DAN SARAN}

\section{Kesimpulan}

Bangsa ayam birma merupakan strain ayam yang mempunyai kualitas semen sangat baik secara kuantitatif maupun secara kualitatifdalam mempertahankan motilitas dan abnormalitas spermatozoa setelah penyimpanan pada suhu $4^{\circ} \mathrm{C}$ dibandingkan dengan bangsa ayam ketawa dan bangsa ayam arab.

\section{Saran}

Perlu dilakukan penelitian lebih lanjut terhadap jenis bangsa ayam lain, agar dapat dijadikan pembanding sehingga akan mendapatkan breed yang baik dan dapat diaplikasikan ke masyarakat peternak untuk meningkatkan produktifitas ternak ayam melalui teknologi Inseminasi Buatan

\section{DAFTAR PUSTAKA}

Bakst, M.R and H Cecil. 1993. Effect of Moficasion of semen Diluent With Cell Culture Serum Replacemen on Fres Stored Turkey Semen Quality and hen Fertility. Journal Agricultural.Vol 13. (4) Hal. 125-133

Burrows, W.H and J.A. Quinn, 1985. AMethode of Oftaining Spermatozoa From Domestic Fowl. Poultry Science.

Chandolia, R.K Reinersten and P.J Hansen. 1999. Lack of Breed Differences in Responses of Bovine
Spermatozoa to Heat Shock. Journal. DairySci. $82:$ 2617-2619.

Evans, C.and Maxwell. 1987. Salomon's Artificial Insemination of sheep and Goats. Butter Woths Pty Ltd Collingwood. Victoria

Hidajat, K. 2000. Pengaruh Berbagai Macam Pengencer dan Dosis Inseminasi Terhadap Periode Fertil Sperma dan Daya Tetas Telur. Skripsi. Fakultas Pertanian UNPAD. Bandung

Irastuti, 2007. Pengaruh Jenis Pengencer Semen terhadap Fertilitas dan Periode FertileSpemetozoa Ayam. Skripsi. Jurusan Peternakan Fakultas Pertanian Universitas Tadulako, Palu

Kartasudjana, R. 2001. Teknik Inseminasi Buatan Pada Ternak. Modul Program Keahlian Budidaya ternak. Departemen Pendidikan Nasional Proyek Pengembangan Sistem Standar Pengelolaan SMK. Direktorat Pendidikan Menengah Kejuruan. Jakarta

Nalbandov, A.V. 1990.Fisiologi Reproduksi pada Mamalia dan Unggas. Judul asli : Reproduction Physiology Of Animals and Birds. Penerjemah : Sunaryo Keman Universitas Indonesia. Jakarta.

Partodiharjo, S. 1992. IImu Reproduksi Hewan. Mutiara Sumber Widya. Jakarta

Purwanti,S. 2006. Pengaruh Penggunaan Berbagai macam Pengenceran terhadap, Motilitas, $\mathrm{pH}$ dan Daya Hidup Spermatozoa Selama Proses Pembuatan Semen Beku Ayam 
kampong. Tesis. Universitas Diponegoro. Semarang

Purwanti, S. 2006. Pengaruh Penggunaan Berbagai Macam Penganceran terhadap Motilitas, $\mathrm{pH}$ dan Daya Hidup Spermatozoa Selama Proses Pembuatan Semen Beku Ayam Kampung. Tesis. Universitas Diponegoro. Semarang.

Ridwan, 2002. Fertil life dan Periode Fertil Spermatozoa Ayam Buras Pasca Inseminasi Buatan. Tesis. Bandung. Program PascasarjanaUniversitasPadjadjar an Bandung.

Salmin, 2000. Pengaruh Kadar Gliserol Dalam Pengencer Susu Skim dan Lama Ekuilibrasi Terhadap Kualitas Spermatozoa Domba Pasca Pembekuan. Tesis. Program Pasca Sarjana. Universitas Padjajaran. Bandung.

Shophiani, 2006. Pengaruh Frekuensi Penampungan Terhdap Volume Semen dan Motilitas Spematozoa Ayam Kampung. Skripsi. Fakultas Peternakan Universitas Diponegoro. Semarang
Situmorang, P. 2002. The Effects of Inclusion of Exogenous Phospolipid In Tris Diluent Containing A Different Level of Egg Yolk on the Viability of Bull Spermatozoa. Pusat Penelitian dan Pengembangan Peternakan dan BadanPenelitian dan Pengembangan Pertanian.Jurnal IImu Ternak dan Veteriner 7 (3) : 131-187

Steel R.G.O and J.H Torrie. 1991. Prinsip dan Prosedur Statistik. Edisi Kedua Gramedia. Jakarta.

Strukie, PD. 1986. Reproduction in The Female and Reproduction in The male. Dalam P.D. Strukie (Ed) Afian Physiology. $4^{\text {th }}($ Ed) Springer Verlag. NewYork.

Suprijatna, E.U, Atmomarsono dan R. Kartasudjana. 2005. IImu Dasar Terbak Unggas. Cetakan 1. Penerbit Swadaya, Jakarta.

Toelihere, MR. 1993. Inseminasi Buatan Pada Ternak. Cetakan ke III. Penerbit Angkas 